\title{
A Story in the Telling
}

\author{
Margaret Kovach
}

\begin{abstract}
Story is experience held in memory and story is the spark for a transformative possibility in the moment of its telling. The words we use are equally significant. This commentary reflects upon why words, stories, and oracy are powerful in learning landscapes. Indigenous peoples have known the value of story and the significance of words in creating and sustaining relationships. In an era of Truth and Reconciliation as Canadian postsecondary institutions seek to indigenize, the words we use and the stories we share will matter.
\end{abstract}

People say that what we're all seeking is a meaning for life. I don't think that is what we're really seeking. I think that what we're seeking is an experience of being alive, so that our life experience on the purely physical plane will have resonances within our own innermost being and reality, so that we actually feel the rapture of being alive. (Campbell, Moyers, \& Flowers, 1991, p. 1)

Stories give our life meaning. Stories gift us with "an experience of being alive." Since childhood, I have been a story listener. I devoured stories in any form. Stories from the talk of the kitchen table. Stories of weather on its way and stories of the first crocuses of Spring; stories of haunting ghosts spilling from my Aunties' memories; hushed stories of adult duplicities that the grown-ups didn't think the kids could hear. And the bedtime stories. I loved the eclectic bedtime stories that either mom or I would read; stories that would entrench in my imagination a diverse crisscrossing world of Jean Valjean and Rapunzel. Too young to unpack Rapunzel, I saw her as a girl with a room and options for letting her hair down. To me, back then, she was a woman with space and choices. The stories of my childhood ignited a spark, an early flash of a budding social consciousness. I return to those stories. We return to our stories because they tell us who we are.

I started in this world as a story listener. At three months of age, my parents adopted me. I grew up in a White rural farming community, but was not born to it. I was born in Saskatchewan and raised there. I am Cree-Saulteaux. From the start, I knew I was adopted but I didn't know about the first three months of my life. I did not know where I came from. Nor did I have an inkling of how my identity was interwoven with the social, political, and economic narrative of my country. But, I knew there was a story there. I share this with you so that you know why stories loom large for me; they always have.

With a curiosity embedded early in life prompting an insatiability for story, it is no wonder that I became an academic. Academics create, channel, receive, and involve ourselves in story all the time. Teaching and research is not possible without chronicling knowledge through descriptive accounts relevant to life. As an Indigenous academic, without story there is no academic me. As Cree Scholar Shawn Wilson says, Research is Ceremony (2008). Story is ceremony. 
The narratives we share with others and those we silently hold in memory compel me. Increasingly I am ensorcelled by story as an animated, in-the-moment happening in the presence of companions: story as event; story as relational; story as a moment. And because I am an Indigenous professor, oral stories are of deep cultural significance. This meandering commentary is a story in itself with some bookish bits woven within. It is a sharing of my recent thoughts on story as happening and a word or two about Indigenous oracy in academia.

August 2017, I had one of those stop-in-your-tracks reckonings as I was sitting in a Kitsilano (Kits) Café on an unimaginably beautiful Vancouver, B.C. morning. It struck me that in an effort to streamline my academic life, it was beginning to mirror the advice I was giving to my research class on developing a well-crafted research question: keep it narrow, focused, and achievable. My intellectual life was feeling algorithmic with an absence of soulfulness, and I knew action was needed.

I was not in the midst of an interpersonal crisis, but was experiencing an intellectual craving. In the past several years I noticed a domesticity settling in and like Leonard Cohen's "Bird on a Wire" (1969, track 1), I could no longer tell if I was free or caged. The remedy, I knew, meant resuscitating my natural inquisitiveness that brought me to academia in the first place. Reigniting my curiosity meant returning to story. Story would breathe life into the flatness, but I needed a strategy. My plan was modest and achievable. I would select a book, wake up at six in the morning, make a coffee, and read a chapter. After finishing one book, I would straightway start a new one.

Over the year, I read books, lots of books-academic books, books from popular culture-all kinds of books. They were mostly nonfiction, but within each book there was story woven throughout. I like reading, so it wasn't a drain. At first, I noticed that I was reading for content but then somewhere, by October, there was a shift and I noticed that I was falling asleep at night anticipating my morning reading event with an author. After my sunrise reading, I shared the ideas and stories with my spouse (he is also an academic) and the stories came alive. My morning book reading shapeshifted from a cerebral exercise to a relational happening and it became a morning ceremony of sorts.

Events, happenings, ceremonies. I began to think about what they meant in my life. I thought of ceremonies in both my Indigenous and European culture: Sweat Lodges and Baptismals, Powwows and Fowl Suppers. One of my morning books was Gilles Deleuze: Key Concepts by Charles J. Stivale (2005). Deleuze thought on the significance of the "event" and what he identified as an "assemblage." The Deleuzian perspective of the "event," as articulated by philosopher James Williams (2014), is "... openness and chance in the present. It is guided by the future and the past, not assumed as burdens, but welcomed as gifts to be worthy of" (p. 90). From my understanding, the Deleuzian event is about the merging of past and future in a present moment of connecting, merging, becoming. An assemblage is a coming together for which an event can occur.

Deleuze's appreciation for mutability and connectivity reminded me of the fluidity of Indigenous thought that exists "... outside the box of linear fragmentation, seeing beyond and across separations, categories, and disciplines. It is wholistic, meta-paradigmatic and timeless, connecting old and new..." 
(Parry, 2015, p. 258). I can imagine my great, great grandmother sharing a story or two with another. Stories of chores and children, of pemmican and medicines. It is an assemblage and Kokum is careful with stories and words because she knows what Cree oral historian Winona Wheeler (2010) reminds us: "Words have great power. They can heal, protect, and counsel, but they can also harm." "manitôkiwin" Winona says. Speaking words to another is "doing something in a holy manner, making something sacred, making ceremony" (p. 55). I imagine Kokum speaking, sharing story, choosing words, discerning, nodding, intonating. Words matter because they sustain relationships and keep communities connected.

Story offers the promise of sharing and hearing, affording us a moment of affinity with another. Through its power of connectivity in the moment, story holds transformative potential. Kahneman and Riss (2005) argue that an individual's perception of well-being arises from two different processes that include the "experiencing self" and the "remembering and evaluating self" (p. 285). They point out that it is the remembering self, rather than the experiencing self, that influences our intrapsychic perceptions of wellbeing. According to Kahneman and Riss, memory and the story of an experience in its aftermath is powerful in determining our perception of an event; however, they give due regard for in-the-moment experience. They say: "We have argued that the experiences that make the moments of life worth living deserve to be studied" (p. 300). They add, "we have urged that the experiencing self be given due regard in well-being research" (p. 300). Story is the consequence of an event and the event itself and is a catalyst for "meta-paradigmatic" connectivity, a Deleuzian "event," and the experience of "the moments of life."

Story, Indigenous-style, is relational, animated, oral; and yet, I sit, my fingers pressing letters lightly on my keyboard. I am writing. I am an academic. Academics are conjurers of the narrative. I am writing now because as an academic it is what we do. My currency, beyond all else, is the written, published word. Knowledge on paper. Expository writing. Academics explain and use the written word to provide evidence. The term "publish or perish" is engrained in the psyche of the western world academic. Published writing is what counts and it is what is counted. We need to honor the written words. But I am also an Indigenous academic. My bloodline summons connection. I work in and through Indigenous Knowledges. My scholarship demands that I respect orality as a relational encounter that my community requires. We need to honor spoken words.

Words offered in the presence of our community is a requirement of the Indigenous academic who works through Indigenous knowledges. It is what gives us credibility and currency. This currency arises from precontact Indigenous philosophy that is wedded in orality. This was recognized and confirmed in the 1997 Canadian Supreme Court decision on oral testimony in Delgamuukw vs British Columbia. ${ }^{1}$ In reflecting on Delgamuukw and the oral testimony given, Chamberlain (2004) writes:

For the Gitksan, the ada'ox Mary Johnston performed was proof of the truth of the events it described: that is to say, the storytelling tradition itself, with its stylized language and its ceremonial protocol, was its own guarantor of truth. (p. 147)

For Indigenous peoples, oracy is fundamental in knowledge dissemination and truth claims. Oracy, and the relationship it creates and sustains, remains primary to Indigenous culture. Without its due recognition, a shadow is cast upon indigenization as put forward by universities. 
In Canadian universities, abstract language of indigenization, decolonization, and reconciliation are molded to align with the language of institutional plans, strategies, and mandates: words, words, words. At times it feels like Polonius and Hamlet trying to figure it out. Coyote dances across my keyboard, the trickster with a secret smile, raises a brow: "Maybe there is more than parched words in the full story?" I think, hmm, yes, there is healing words, felt words, meaningful words, trustworthy words, this is also a part of the story.

Narratives give space for transformative possibilities in teaching and learning, and story is implied in research discoveries. This includes quantitative research where, we know, that behind every statistic there is a story. Story is a powerful communicative event. It is the sharing of story, the witnessing of story, and the learning from story that the Indigenous Elders know hold the potential for shifts in consciousness. This is a transformative shift that first happens in a performative testimonial space that is viscerally known in the relationships that embrace story. For me, as a critical educator, this is where social justice starts. Story is how we will decolonize teaching and research. Story is how we will decolonize the academy...

It is Spring 2018, and the academic year is coming to an end. The conversations, connections, and stories of this past year flicker and move through my mind as I conclude this commentary. I close with a thankyou to my students for allowing me to see that, although we may live in a world full of birds on wires, birds we still are. And to all who have gifted me this year through morning book dialogues, womyn's assemblages, office talks and skype calls, and the generosity of spirit as you found my rambling emails in your inbox. You've kept me engaged. You reminded me that story is ceremony. Miigwetch, Ekosi.

\section{Note}

1. In the 1997 Delgamuukw case (Delgammukw v Queen), the Supreme Court of Canada affirmed that oral testimony as evidence must be given equal treatment as other forms of evidence.

\section{References}

Campbell, J., Moyers, B. D., \& Flowers, B. S. (1991). The power of myth. New York, NY: Anchor Books.

Chamberlain, J.E. (2004). If this is your land where are your stories? Reimaging home and sacred space. Cleveland, OH: Pilgrims Press.

Cohen, L. (1969, Track 1). Bird on a wire. Songs from a room. Nashville, TN: Bob Johnston.

Kahneman, D., \& Riis, J. (2005). Living and thinking about it: Two perspectives on life. In N. Baylis, Felicia A. Huppert, \& B. Keverne (Eds.), The science of well-being (pp. 285-301). Oxford University Press.

Parry, G. A. (2015). Original thinking - A radical revisioning of time, humanity, and nature. Berkeley, CA: North Atlantic Books.

Stivale, C.J. (Ed.). (2005). Gilles Deleuze: Key concepts. Montreal, Quebec: McGill-Queen's University Press. 
Wheeler, W. (2010). Cree intellectual traditions in history. In A. Finkel, C. Carter, \& P. Fortna (Eds.), In the West and beyond: New perspectives on an imagined region (pp. 47-61). Athabasca, Alberta: Athabasca University Press.

Williams, J. (2014). Events. In C.J. Stivale (Ed.), Gilles Deleuze: Key concepts (pp. 80-90). New York, NY: Routledge.

Wilson, S. (2008). Research is ceremony - Indigenous research methods. Winnipeg, Manitoba: Fernwood Press.

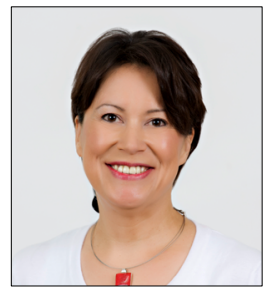

Margaret Kovach is of Plains Cree and Saulteaux ancestry and a member of Pasqua First Nation located in southern Saskatchewan. She is currently a Professor at the College of Education, University of Saskatchewan, Canada. Dr. Kovach's work focuses on Indigenous research methodologies and Indigenous postsecondary education. She is an internationally recognized scholar in the field of Indigenous methodologies. Dr. Kovach's publication and presentations have had a significant impact in her field.

Of note is her book, Indigenous Methodologies: Characteristics, Conversations, and Contexts, published through the University of Toronto Press. Dr. Kovach is a Member of the College of the Royal Society of Canada. 
54 | LEARNing Landscapes | Spring 2018, Vol. 11 No. 2 